\title{
Wiesław Sieciński
}

Uniwersytet Szczeciński

e-mail:wieslaw.siecinski@univ.szecin.pl

\section{Administracja szkolnictwa powszechnego i średniego w II Rzeczypospolitej}

\begin{abstract}
STRESZCZENIE
Po odzyskaniu przez Polskę niepodległości w 1918 r. wzrosło zainteresowanie społeczne sprawami oświaty i wychowania. Odziedziczone po państwach zaborczych systemy edukacji wymagały ujednolicenia na terenie całego państwa. Powszechne było przeświadczenie, że w odrodzonym państwie polskim niezbędne są podstawowe akty rządowe likwidujące dotychczasowe zróżnicowanie dzielnicowe i zapewniające zwartą oraz jednolitą organizację szkolnictwa i oświaty w całym kraju.
\end{abstract}

Kierownictwo administracją szkolnictwa należało do ministra wyznań religijnych i oświecenia publicznego. Dla celów administracji szkolnej kraj został podzielony na 10 okręgów szkolnych z kuratorami na czele. Okręgi dzieliły się na obwody szkolne pod kierownictwem inspektorów szkolnych. Odziedziczone po państwach zaborczych systemy edukacji zostały ostatecznie ujednolicone na mocy ustawy w 1932 r. Przeprowadzona reforma podzieliła szkoły na powszechne, średnie i wyższe. Ze względu na źródło finansowania wyróżniono szkoły publiczne i prywatne. Zasadę stanowić miało siedmioletnie nauczanie w zakresie szkoły powszechnej. Jednak w celu zakwalifikowania istniejących szkół do nowego modelu organizacyjnego wprowadzono trójstopniowy podział szkół powszechnych, na szkoły realizujące:

- program elementarny (klasy I-IV),

- program wyższy (klasy I-VI),

- program pełny (7 klas).

Na średnie szkolnictwo ogólnokształcące składać miały się po reformie 4-letnie gimnazja oraz jako szczebel wyższy - 2-letnie licea. Do gimnazjum przyjmowano (po złożeniu egzaminu) uczniów, którzy ukończyli 6 klas szkoły powszechnej. Po ukończeniu gimnazjum i zdaniu egzaminu wstępnego można było kontynuować naukę w liceum, po której ukończeniu możliwe było przystąpienie do egzaminu dojrzałości, a następnie podjęcie studiów w szkole wyższej. Ustawa z 1932 r. umożliwiła zorganizowanie na analogicznych zasadach szkół zawodowych.

\section{SŁOWA KLUCZOWE}

historia administracji, szkolnictwo II RP 


\section{Wprowadzenie}

Nowy ład polityczny i społeczny, który ukształtował się w Polsce w wyniku pierwszej wojny światowej spowodował wzrost zainteresowania społecznego sprawami oświaty i wychowania. Organizację szkolną funkcjonującą w pierwszych latach niepodległości, zróżnicowaną na poszczególnych obszarach kraju, traktowano jako przejściową. Zarówno w kręgach rządowych, jak i w środowiskach nauczycielskich istniała świadomość potrzeby ujednolicenia systemu oświatowo-wychowawczego na terenie całego państwa. Już pierwsze próby stworzenia założeń reformy szkolnej wykazały jednak złożoność tego zadania. Trudności były różnorakiej natury, wynikały zarówno ze zróżnicowanych poglądów na podstawy ustroju szkolnego Rzeczypospolitej, jak i ze struktury wielonarodowego państwa, pełnego głębokich dysproporcji ekonomicznych i kulturowych.

Sprawa zasadniczej reformy ustroju oświatowo-wychowawczego zaprzątała uwagę środowisk rządowych i politycznych od pierwszych lat niepodległości. Reforma była niezwykle oczekiwana przez społeczeństwo i środowiska nauczycielskie. Powszechne było przeświadczenie, że w odrodzonym państwie polskim niezbędne są podstawowe akty prawne likwidujące dotychczasowe zróżnicowania dzielnicowe i zapewniające zwartą oraz jednolitą organizację szkolnictwa i oświaty w całym kraju.

Ustawę o ustroju szkolnictwa, wniesioną pod obrady parlamentu przez ministra Janusza Jędrzejewicza, uchwalono 11 marca 1932 r. W nowym roku szkolnym 1932/1933 na podstawie tej ustawy zasadniczo przebudowano ustrój szkolny Rzeczypospolitej. Ustawa o ustroju szkolnictwa z 1932 r. ustaliła jednolity system szkolny w Polsce obowiązujący do schyłku II Rzeczypospolitej. Był to akt doniosły i w wieku sprawach stanowił znaczny postęp w stosunku do stanu poprzedniego.

\section{Charakter i wartość szkolnictwa odziedziczonego po zaborcach}

Na system szkolny tworzony w Polsce po 1918 r. silny wpływ wywarł z jednej strony układ stosunków społecznych i przebieg walk o ustrój państwa, a z drugiej strony spuścizna oświatowa po zaborcach oraz dorobek pedagogiczny społeczeństwa polskiego tworzony głównie przez organizacje oświatowe, związki nauczycielskie i szkolnictwo prywatne.

Przejęty po zaborcach ustrój szkolny, będący dziełem formacji feudalnej i kapitalistycznej, miał na wszystkich ziemiach polskich pewne cechy wspólne, jednak odrębności w systemach ekonomicznych, politycznych, społecznych i prawnych Prus, Austrii i Rosji spowodowały, że były dość poważne różnice w ich szkolnictwie pod względem organizacyjnym, programowym i dydaktycznym. Oprócz tego zarysowały się pewne różnice w poziomie nauczania i wychowania oraz w stanie ilościowym szkół w obrębie ziem polskich poszczególnych zaborów. W celu wynarodowienia ludności polskiej, niemieckie czy rosyjskie klasy rządzące starały się popierać procesy dezintegracyjne, wykorzystując wszelkie okazje do wzmocnienia odrębności poszczególnych ziem polskich, stosując na nich zróżnicowaną politykę ekonomiczną narodowościową i oświatowo-kulturalną. Dlatego też np. na terenie byłego zaboru rosyjskiego inny charakter miała sieć szkolna i system organizacyjny 
szkolnictwa początkowego w tzw. Królestwie Polskim, a inny na włączonych do Rosji pozostałych ziem I Rzeczypospolitej. Również na terenach zaboru pruskiego istniały różnice między szkolnictwem ludowym Śląska, Pomorza i Poznańskiego. W zaborze austriackim sporo odrębnych cech ukształtowało się przede wszystkim w szkolnictwie Galicji Wschodniej i Zachodniej oraz na terenie Śląska Cieszyńskiego ${ }^{1}$. Oprócz oddziaływania systemu ekonomicznego i politycznego zaborców, na jakość i charakter szkolnictwa poszczególnych ziem polskich wpłynęła także sama ludność polska - jej sytuacja ekonomiczna, struktura klasowa oraz aktywność społeczna.

Walka o system oświatowy i wychowawczy toczyła się zarówno między Polakami a zaborcami, jak i wewnątrz samego społeczeństwa polskiego, między jego klasami społecznymi i ugrupowaniami politycznymi. Poważną rolę odegrały także wzajemne stosunki między ludnością polską a współżyjącymi z nią innymi narodowościami ${ }^{2}$. Brak nauczycieli był tak wielki, iż na ziemiach byłego zaboru rosyjskiego i pruskiego przyjmowano do pracy jako nauczycieli kandydatów, którzy mieli ukończone zaledwie kilka klas szkoły średniej ${ }^{3}$.

\section{Kształtowanie się systemu oświatowo-wychowawczego}

System oświaty w okresie międzywojennym nie może być traktowany jednolicie. Oświata w okresie dwudziestolecia międzywojennego przechodziła zarówno fazy rozwoju, jak i stagnacji, co powiązane było z ówczesną sytuacją polityczną ${ }^{4}$. Nowy ład polityczny i społeczny, który ukształtował się w wyniku wojny światowej, spowodował przyspieszenie rozwoju pedagogiki oraz ogromny wzrost zainteresowań społecznych sprawami oświaty i wychowania ${ }^{5}$. Na charakter i kierunek ówczesnej polityki oświatowej wpływ miały w pierwszej kolejności orientacje oraz dążenia rządzących stronnictw politycznych, natomiast wyniki wspomnianej polityki zastosowane w praktyce warunkowane były:

a) przeprowadzeniem scalenia poszczególnych dzielnic kraju w jednolity organizm państwowy z ustalonymi granicami terytorialnymi;

b) sytuacją ekonomiczną kraju;

c) układem sił politycznych;

d) stanem szkolnictwa odziedziczonego po zaborcach.

Podstawowe założenia polityki oświatowej rządu Jędrzeja Moraczewskiego ${ }^{6}$ oraz dążenia nauczycielskie wspierane przez postępową część opinii publicznej, ale jednocześnie ostro zwalczane przez obóz konserwatywny, znalazły wyraz oficjalny w deklaracji Tymczasowego Rządu Ludowego z dnia 20 listopada 1918 r., w której sformułowano zasadniczy

1 K. Trzebiatowski, Szkolnictwo powszechne w Polsce w latach 1918-1932, Zakład Narodowy im. Ossolińskich, Wydawnictwo PAN, Wrocław-Warszawa-Kraków 1970, s. 20.

2 Historia wychowania. Wiek XX, red. J. Miąso, PWN, Warszawa 1984, s. 25.

3 M. Falski, Fragmenty prac z zakresu oświaty 1900-1944, Zakład Narodowy im. Ossolińskich, Wydawnictwo PAN, Wrocław-Warszawa-Kraków-Gdańsk 1974, s. 272.

4 B. Suchodolski, Edukacja narodu 1918-1968, Wiedza Powszechna, Warszawa 1970, s. 14.

5 R. Wroczyński, Dzieje oświaty polskiej, t. 2: 1795-1945, Wydawnictwo Edukacyjne „Żak”, Warszawa 1996, s. 245.

6 W. Witkowski, Historia administracji w Polsce 1764-1989, Wydawnictwo Naukowe PWN, Warszawa 2007, s. 303-304. 
kierunek reform oświatowych ${ }^{7}$. Czytamy w niej m.in.: „Jednym z najważniejszych naszych zadań będzie stworzenie powszechnej, świeckiej, bezpłatnej szkoły, dostępnej jednakowo dla wszystkich, bez względu na stan majątkowy. Tylko zdolności mają decydować o przywileju wyższego wykształcenia. Będziemy budzili wśród ludu ducha obywatelskiego i poczucie odpowiedzialności za losy państwa, które jest jego państwem. Staraniem naszym będzie wydobycie dla narodu tych licznych talentów, które wskutek niedostępności wyższej oświaty dla szerokich warstw ludowych dotychczas się marnowały".

Istotny wpływ na możliwość przeprowadzenia reform szkolnych wynikających z założeń rządu miała sytuacja gospodarcza Polski, a była ona więcej niż krytyczna ${ }^{9}$. Warunki startu Polski w niepodległość były złożone i pod każdym względem trudne. Trudności te znalazły odzwierciedlenie w tworzonym systemie edukacji i miały wpływ na realizację założeń programu. System edukacji, ukształtowany w sposób gwarantujący realizację wyznaczonych mu funkcji, w szczególności przygotowanie młodego pokolenia do życia i pracy w odradzającym się państwie, musi mieć odpowiednie warunki i zasoby, w tym ustalony i sprawnie funkcjonujący ustrój szkolnictwa, wykrystalizowaną ideologię wychowawczą oraz wytyczoną politykę oświatowo-wychowawczą. W Polsce w momencie odradzania się po latach zaborów wszystkie wymienione powyżej elementy sprawnego funkcjonowania systemu oświaty dopiero się kształtowały, a niektóre $\mathrm{z}$ nich znacznie odbiegały od założeń przez całe międzywojenne dwudziestolecie. Dopiero po wprowadzeniu w życie ustawy z 11 marca 1932 r. można było mówić o ustrojowo-programowej jednolitości szkolnictwa, jak również o pełnym podporządkowaniu go władzom państwowym. Przed wejściem tej ustawy w życie, państwo miało całkowity wpływ jedynie na szkolnictwo powszechne, a nie miało takiego wpływu na szkolnictwo na szczeblu średnim, zwłaszcza ogólnokształcącym, z uwagi na fakt, iż to $w$ dwóch trzecich było prywatne. Ograniczało to w dużym stopniu wpływ państwa na potrzeby wychowania obywatelsko-państwowego. Konieczność przeprowadzenia reform szkolnictwa postrzegana była w różny sposób przez różne ugrupowania polityczne. Dominował wówczas klasowy charakter ideologii, co oznaczało, że założenia ideologii wychowawczej państwa będą odzwierciedleniem dążeń tych klas ${ }^{10}$, bez spójnego, ogólnopaństwowego, ponadpartyjnego modelu wychowawczego. Prawica silnie optowała za tym, aby szkolnictwo zachowało charakter elitarny i wyznaniowy. Przedstawiciele partii rewolucyjnych prowadzili intensywne prace nad przygotowaniem socjalistycznego systemu oświatowo-wychowawczego. Rady Delegatów Robotniczych zauważały potrzeby oświatowe ludu pracującego i domagały się m.in. bezpłatnej i obowiązkowej szkoły podstawowej dla dzieci i młodzieży od 7 do 16 lat oraz zapewnienia dzieciom z rodzin robotniczych bezpłatnych materiałów szkolnych, obuwia i posiłków. Żądając dziewięcioletniej bezpłatnej szkoły i obowiązkowej szkoły podstawowej, jednakowo dostępnej dla wszystkich dzieci, rewolucyjny ruch robotniczy dążył do wydźwignięcia mas pracujących z zacofania kultu-

7 B. Suchodolski, op. cit., s. 31.

8 F.W. Araszkiewicz, Szkoła średnia ogólnokształcąca w Polsce w latach 1918-1932, Zakład Narodowy im. Ossolińskich, Wydawnictwo PAN, Wrocław-Warszawa-Kraków-Gdańsk 1972 s. 14.

9 W. Witkowski, op. cit., s. 253.

10 F.W. Araszkiewicz, Ideały wychowawcze Drugiej Rzeczypospolitej, PWN, Warszawa 1978, s. 88-89. 
ralnego. W żądaniu tym tkwiła zapowiedź walki o zreformowanie elitarnej ośmioletniej szkoły ogólnokształcącej ${ }^{11}$.

Pierwszy rząd Drugiej Rzeczypospolitej - rząd Jędrzeja Moraczewskiego - zaczął wypracowywać ideologię wychowawczą ze stanowiska reprezentowanych w nim stronnictw, głównie Polskiej Partii Socjalistycznej i Polskiego Stronnictwa Ludowego „Wyzwolenie”12. Kierowanie oświatą w rządzie Jędrzeja Moraczewskiego przypadło w udziale Ksaweremu Praussowi, znanemu nauczycielowi szkół średnich, wieloletniemu działaczowi Polskiej Partii Socjalistycznej, byłemu kierownikowi Centralnego Biura Szkolnego, a od 1917 r. członkowi władz naczelnych Zrzeszenia Nauczycielstwa Polskich Szkół Początkowych ${ }^{13}$. To wszystko, co na temat oświaty i wychowania bardzo ogólnie wyrażano w odezwie rządu Jędrzeja Moraczewskiego, znalazło rozwinięcie w programie oświatowym Ksawerego Praussa, wypracowanym przy udziale przedstawicieli postępowych związków nauczycielskich, zrzeszających większość nauczycieli szkół początkowych i średnich ${ }^{14}$.

W grudniu 1918 r. Ministerstwo Wyznań Religijnych i Oświecenia Publicznego (MWRiOP) ogłosiło program zwany „programem Praussa”, w którym czytamy m.in. następujące zasady organizacji szkolnictwa:

Obowiązek szkolny ma trwać 7 lat. Organa samorządu będą mogły go przedłużyć w porozumieniu z MWRiOP. Szkoła powszechna będzie przeznaczona dla wszystkich sfer społecznych. Zdolniejsi uczniowie będą kierowani ze szkoły powszechnej do szkół wyższego typu. Szkoła powszechna ma być bezpłatna dla wszystkich. Administracja szkolna i nadzór nad szkołą ma należeć wyłącznie do władz świeckich. Pomiędzy szkołami powszechnymi, najniżej nawet zorganizowanymi, a szkołami wyższymi musi być zachowana taka ciągłość programu, aby zdolniejsi uczniowie najszerszych warstw włościańskich i robotniczych mogli z zupełną łatwością przechodzić ze szkół najniższych typów do najwyższych. Tylko zdolności oraz zalety charakteru mają otwierać drogę do wyższego wykształcenia. Reformy dotyczące organizacji szkół średnich ogólnokształcących polegać mają na wydzieleniu niższych klas i połączeniu ich ze szkołą powszechną oraz na utworzeniu klas wyższych 5-letniego gimnazjum kilku typów. Nowe programy będą zdążały do wyrobienia w młodzieży zdolności obserwacji i krytycznego myślenia, do wdrażania w czynność samodzielną i uczenia metod pracy. W szerokim zakresie ma być wprowadzona nauka o Polsce współczesnej, która zaznajomi młodzież z najważniejszymi dziedzinami i zagadnieniami życia bieżącego ${ }^{15}$.

Wprowadzenie w życie zasad obowiązkowego wykształcenia podstawowego nie było łatwe $\mathrm{z}$ uwagi na zdecydowany sprzeciw zwolenników ośmioletniego gimnazjum, opartego na 4-letniej szkole podstawowej.

Po krótkich rządach Jędrzeja Moraczewskiego wiele podstawowych założeń programu oświatowo-wychowawczego, pod kierunkiem Ksawerego Praussa, przejął rząd Ignacego Paderewskiego, jak również kilka następnych gabinetów. Kontynuacja założeń programu oświatowo-wychowawczego przez kolejne ekipy rządzące była możliwa dzięki uniwersalne-

11 Idem, Szkoła średnia..., s. 16.

12 Idem, Ideały wychowawcze..., s. 94.

13 Idem, Szkoła średnia..., s. 17.

14 Idem, Ideały wychowawcze..., s. 94.

15 B. Suchodolski, op. cit., s. 28. 
mu charakterowi tych założeń. Nie stanowiły one zagrożenia dla rządzących, a w związku ze znacznym stopniem ogólności jego sformułowań mogła do nich $\mathrm{z}$ równym powodzeniem nawiązywać zarówno prawica, jak i lewica ${ }^{16}$.

Powstające w 1918 r. państwo dziedziczyło bardzo różne systemy szkolne i różne poziomy powszechności kształcenia. Najwyższy wskaźnik skolaryzacji wykazywał zabór pruski, ale była to szkoła niemiecka. Tworząc szkolnictwo polskie, trzeba było wszystko zaczynać od nowa. Najniższy wskaźnik charakteryzował rozległe tereny zaboru rosyjskiego. Liczba dzieci pozostająca poza szkołą była ogromna, a liczba lat nauczania była niewielka. Lepiej było w Galicji, ale i tam trudno było mówić o powszechności nauczania podstawowego. Jego zaś poziom niewiele wykraczał poza horyzonty tradycyjnej szkoły ludowej. W tych warunkach program powszechnego nauczania był programem niezwykle śmiałym. Dekret o obowiązku szkolnym z lutego 1919 r. oraz ustawa o zakładaniu i utrzymywaniu szkół powszechnych z lutego 1922 r. położyły fundamenty prawne dla realizacji tego planu. Wysokie nakłady finansowe i wielki wysiłek organizacyjny pozwoliły na osiągnięcie znacznych sukcesów w jego realizacji. U schyłku lat dwudziestych powszechność nauczania w zakresie 7-letniej szkoły była na ogół osiągnięta w bardzo wysokim stopniu. Wyjątek stanowiły tereny wschodnie, gdzie takiego poziomu nie udało się osiągnąć.

Procesy upowszechnienia nauczania zostały zahamowane przez kryzys. W 1932 r. z tego powodu poza systemem powszechnego szkolnictwa znalazły się setki tysięcy dzieci, a jednolitość systemu nauczania na poziomie szkoły podstawowej została zniweczona. Dopiero od 1935 r. rozpoczął się bardzo powolny proces przezwyciężania ograniczeń, świadczący o tym, iż nacisk opinii publicznej i postulaty nauczycielstwa uzyskiwały pewne znaczenie ${ }^{17}$.

\section{Organy administracji oraz organizacja szkolnictwa powszechnego i średniego}

Administracją szkolnictwa w okresie międzywojennym różnych typów i stopni kierował minister wyznań religijnych i oświecenia publicznego. Dla celów administracji oświatowej kraj został podzielony na 10 okręgów szkolnych, które dzieliły się na obwody obejmujące jeden lub więcej powiatów. Obwodami kierowali inspektorzy szkolni. Pełnili oni funkcje organów administracji szkolnej pierwszej instancji w zakresie kierowania i nadzoru nad szkolnictwem powszechnym, publicznym i prywatnym. Na czele okręgu szkolnego stał kurator, którego organem pomocniczym było kuratorium.

Wytyczne dla organizacji szkolnictwa zostały zawarte w konstytucji marcowej z 17 marca 1921 r., która gwarantowała:

a) wolność badań naukowych i ogłaszania ich wyników;

b) obowiązek nauki dla wszystkich dzieci w zakresie szkoły powszechnej (podstawowej);

c) bezpłatność nauki w szkołach państwowych i samorządowych;

16 F.W. Araszkiewicz, Ideały wychowawcze..., s. 95.

17 M. Pęcherski, M. Świątek, Organizacja oświaty w Polsce w latach 1917-1969. Podstawowe akty prawne, PWN, Warszawa 1972, s. 27; B. Suchodolski, op. cit., s. 40. 
d) obowiązek nauki religii dla młodzieży do lat $18 \mathrm{w}$ szkołach utrzymywanych przez państwo i samorząd pod dozorem właściwego związku religijnego;

e) prawo każdego obywatela do założenia i prowadzenia szkoły lub zakładu wychowawczego pod nadzorem organów administracji szkolnej ${ }^{18}$.

Konstytucja marcowa w artykule 120 postanowiła, że w każdym publicznym zakładzie naukowym, którego program obejmuje kształcenie młodzieży poniżej 18 lat, nauka religii jest obowiązkowa dla wszystkich uczniów ${ }^{19}$. Zasady te, z wyjątkiem bezpłatności nauki, zostały przejęte przez konstytucję kwietniową.

Druga Rzeczpospolita przejęła po państwach zaborczych trzy różne systemy szkolne. W pierwszych latach rozpoczęto prace nad ujednoliceniem organizacji programów nauczania. Pełną unifikację, a zarazem reorganizację gwarantowała ustawa z 1932 r. ${ }^{20}$ Dzieliła ona szkoły ze względu na stopień nauczania na szkoły powszechne, szkoły średnie i szkoły wyższe. Z punktu widzenia źródeł finansowania wyodrębniono szkoły publiczne, utrzymywane przez państwo i samorząd oraz szkoły prywatne, utrzymywane przez organizacje religijne, stowarzyszenia społeczne i osoby prywatne.

Reforma przeprowadzona w 1932 r. wprowadziła trójstopniowy podział szkół powszechnych na szkoły realizujące: program elementarny (klasy 1-4), program wyższy (klasy 1-6), program pełny (7 klas), przewidując zaszeregowanie istniejących szkół do jednego z trzech stopni $^{21}$, przy czym klasa VII w tej szkole była tzw. czapką dla młodzieży kończącej naukę na poziomie szkoły powszechnej. Przejście do szkoły średniej następowało po ukończeniu VI klasy szkoły podstawowej. Odbierało to szkole najwyżej zorganizowanej (trzeciego stopnia) charakter podstawowego ogniwa dalszych szczebli wykształcenia. Szkoła powszechna trzystopniowa stwarzała jedynie pozory jednolitości, w istocie rzeczy była szkołą ostrej selekcji społecznej. Twórcy ustawy z 1932 r. z góry zakładali, ze „czapka” VII klasy będzie zamykać systematyczną 7-letnią naukę ogromnej większości dzieci z rodzin robotniczych i chłopskich ${ }^{22}$.

Wprowadzony w 1919 r. obowiązek nauki w zakresie szkoły powszechnej nie został w pełni zrealizowany w okresie II Rzeczypospolitej. Obowiązek ten obejmował w województwach zachodnich przeszło $95 \%$ dzieci, jednak w województwach wschodnich osiągał w ostatnich latach poziom około $80 \%$. Najpomyślniejszy z tego punktu widzenia był rok szkolny 1928/29, kiedy powszechnym obowiązkiem szkolnym objętych zostało prawie 95\% dzieci. W porównaniu z sytuacją istniejącą na ziemiach polskich w 1918 r., a zwłaszcza w byłym Królestwie Polskim, gdzie do szkół uczęszczało 15\% dzieci, było to poważne osiągnięcie II Rzeczypospolitej. O wiele trudniej było zrealizować obowiązek szkolny w zakresie pełnej szkoły powszechnej. W 1928 r. szkolę 7-klasową kończyło 22\% dzieci, w 1937 r. liczba ta wzrosła do przeszło $40 \%$.

18 J. Bardach, B. Leśnodorski, M. Pietrzak, Historia ustroju i prawa polskiego, Lexus Nexis, Warszawa 2015, s. 520.

19 Ibidem, s. 486-487.

20 J. Malec, D. Malec, Historia administracji i myśli administracyjnej, Wydawnictwo Uniwersytetu Jagiellońskiego, Kraków 2000, s. 166.

21 D. Malec, J. Malec, Historia administracji nowożytnej, Wydawnictwo Uniwersytetu Jagiellońskiego, Kraków 1996, s. 158.

22 R. Wroczyński, op. cit., s. 262. 
Pod względem nasycenia obszaru kraju szkołami 7-klasowymi występowało jaskrawe upośledzenie wsi w stosunku do miast, dzielnic wschodnich w stosunku do zachodnich. Ograniczało to w istotny sposób dostęp do szkoły średniej młodzieży wiejskiej ${ }^{23}$.

Jeśli chodzi o szkolę średnią, to reforma z 1919 r. zachowała 8-letni kurs szkoły średniej ogólnokształcącej. Jedyną w tym zakresie nowością było podzielenie go na dwa szczeble programowe: 3-letni przygotowawczy i 5-letni systematyczny. Pierwszy szczebel otrzymał nazwę gimnazjum niższego, drugi gimnazjum wyższego.

W 1929 r. minister Kazimierz Świtalski rozporządzeniem z dnia 2 stycznia wprowadził pełną drożność programową między 7-klasową szkołą powszechną a gimnazjum niższym, przez redukcję wymiaru godzin i materiału nauczania w tychże szkołach. Podstawowym założeniem było uzgodnienie przedmiotów oraz wymiaru godzin nauki w trzech najwyższych oddziałach szkoły powszechnej i gimnazjum niższym. Dążenia te w pełni zahamowały rozbudowę szkół powszechnych 7-klasowych i rozwijanie gimnazjów niższych. Pewien przyrost liczby gimnazjów wyższych (bez klas wstępnych i trzech niższych) nastąpił dopiero po 1929 r., kiedy to zaczęły powstawać gimnazja 5-letnie. Wprowadzono nowe plany godzin, zmniejszając przeciążenie pracą młodzieży szkół średnich, oraz pełną drożność programową między 7-klasową szkołą powszechną a gimnazjum wyższym ${ }^{24}$, co widać w przykładowym planie lekcji wyższych oddziałów 7-klasowej szkoły powszechnej i gimnazjum niższego podanym w tabeli poniżej.

Tabela nr 1. Tygodniowy plan godzin nauki wyższych oddziałów 7-klasowej szkoły powszechnej i gimnazjum niższego

\begin{tabular}{|l|c|c|c|c|}
\hline \multirow{2}{*}{ Przedmioty } & \multicolumn{2}{|c|}{ Klasy (oddziały) } & \multirow{2}{*}{ Razem } \\
\cline { 2 - 4 } & $\mathrm{I}(\mathrm{V})^{\star}$ & $\mathrm{II}(\mathrm{VI})^{\star}$ & $\mathrm{III}(\mathrm{VII})^{*}$ & 6 \\
\hline religia & 2 & 2 & 2 & 12 \\
\hline język polski & 4 & 4 & 4 & 11 \\
\hline język obcy nowożytni & 5 & 3 & 1 & 5 \\
\hline historia & 2 & 2 & 2 & 5 \\
\hline geografia & 2 & 2 & 5 & 9 \\
\hline nauka o przyrodzie & 2 & 2 & 4 & 12 \\
\hline rachunki z geometrią & 4 & 4 & 2 & 6 \\
\hline rysunek & 2 & 2 & 4 & 10 \\
\hline roboty ręczne & 2 & 4 & 1 & 5 \\
\hline śpiew & 2 & 2 & 3 & 9 \\
\hline ćwiczenia cielesne & 3 & 3 & 30 & 90 \\
\hline Razem & 30 & 30 & & \\
\hline
\end{tabular}

* W nawiasie podane zostały oddziały szkoły powszechnej.

Źródło: F.W. Araszkiewicz, Szkoła średnia ogólnokształcąca w Polsce w latach 1918-1932, s. 176.

Ostateczny kształt szkolnictwa średniego w okresie międzywojennym ustaliła dopiero wspomniana wcześniej „ustawa Jedrzejewiczowska” z 11 marca 1932 r. Ustawa przewidy-

23 Ibidem, s. 251-260.

24 F.W. Araszkiewicz, Szkoła średnia..., s. 177. 
wała, że młodzież po ukończeniu 7-letniej szkoły - nieuczęszczająca do szkół wyższego stopnia - podlegała obowiązkowemu dokształcaniu do ukończenia 18. roku życia. Ogólnokształcąca szkoła średnia była szkołą 6-letnią składającą się z 4-letniego gimnazjum i 2-letniego zróżnicowanego liceum. W szkołach zawodowych wyodrębniono trzy typy szkół zawodowych: dokształcające, zasadnicze i przysposobienia zawodowego. Szkoły te były typu zasadniczego i dzieliły się na niższe, gimnazjalne i licealne. Ustawa o ustroju szkolnictwa z 1932 r. ustaliła ostatecznie jednolity system szkolny w Polsce obowiązujący do schyłku Drugiej Rzeczypospolitej. Podział szkoły średniej na dwa ogniwa: niższe (gimnazjum) i wyższe (liceum), prowadzące do wyższych studiów, nadawał szkole średniej strukturę elastyczną i stwarzał perspektywy szerszego upowszechnienia. Ustanowienie trzech typów liceum: humanistycznego, matematyczno-przyrodniczego i klasycznego, odpowiadać miało strukturze zainteresowań i potrzebom $\mathrm{kadr}^{25}$.

Ustawa z 1932 r. dokonała również przebudowy systemu kształcenia nauczycieli. Likwidacji uległy seminaria nauczycielskie, powołano natomiast 3-letnie licea pedagogiczne oparte na podbudowie szkoły średniej, co zapewniało kadrom nauczycielskim wyższy poziom ogólnego i pedagogicznego przygotowania ${ }^{26}$.

\section{Podsumowanie}

Podstawowym warunkiem realizacji jednolitej polityki oświatowej w niepodległym państwie polskim była konsolidacja władzy szkolnej i ujednolicenie zarządzania szkolnictwem, zróżnicowanym na terytorium byłych zaborów. W połowie 1922 r. unifikacja administracji szkolnej w państwie została zakończona. Wprawdzie zachodziły w późniejszych latach zmiany terytorialne okręgów i obwodów szkolnych, ale zmiany te dokonywały się już w ramach jednolitego systemu zarządzania szkolnictwem, systemu, który - obowiązując w całym kraju - umożliwiał sprawne wcielanie w życie państwowej polityki oświatowej.

Uchwalona przez Sejm 11 marca 1932 r. ustawa o ustroju szkolnictwa dokonała poważnej przebudowy całego systemu szkolnego. Przeprowadzona reforma podzieliła szkoły na: powszechne (podstawowe), średnie i wyższe. Ze względu na źródło finansowania wyróżniano szkoły publiczne i prywatne, utrzymywane ze środków organizacji religijnych, stowarzyszeń, osób prywatnych.

Lata 1929-1936 były niezwykle trudnym okresem dla szkolnictwa polskiego. W końcu 1929 r. zapanował na świecie kryzys gospodarczy o niespotykanych dotąd rozmiarach. Polska, jako kraj o zacofanej ekonomice i przeludnionej wsi, odczuwała skutki tego kryzysu dużo ostrzej i znacznie dłużej niż inne kraje kapitalistyczne. Kryzys spowodował gwałtowny spadek produkcji przemysłowej, poważne zubożenie wsi, wzrost bezrobocia oraz pogorszenie sytuacji materialnej i warunków życia społeczeństwa. Skutki kryzysu odbiły się dotkliwie na sytuacji szkolnictwa, tym bardziej że do szkół powszechnych zaczęły napływać szeroką falą dzieci silnych liczebnie roczników powojennych. W latach 1929-1934 
publiczne szkoły powszechne wchłonęły przeszło milionowy przyrost uczniów, przy równoczesnym obniżeniu liczby etatów nauczycielskich i zahamowaniu budownictwa szkolnego. Z powodu niedoboru nauczycieli szkół powszechnych i braku izb szkolnych z roku na rok obniżała się powszechność nauczania i rosła liczba dzieci pozostających poza szkołą. Brak miejsca w szkołach powszechnych dla wszystkich dzieci był powodem dość częstego rozpoczynania nauki w ósmym roku życia. Spadek ogólnej liczby nauczycieli doprowadził do zahamowania procesu podnoszenia stopnia organizacyjnego szkół powszechnych.

Poczynając od roku szkolnego 1936/37 sytuacja szkolnictwa uległa powolnej poprawie, dzięki ogólnemu polepszeniu położenia gospodarczego kraju oraz wskutek wyraźnego osłabienia tempa przyrostu liczby dzieci w wieku szkolnym. Poprawę organizacyjną szkolnictwa powszechnego należy zawdzięczać uporczywym wysiłkom grupy doświadczonych pracowników administracji szkolnej z dr. Marianem Falskim na czele. Z tych właśnie kręgów wyszła koncepcja szkół zbiorczych, które miały ułatwiać dzieciom wiejskim dostęp do wyżej zorganizowanej szkoły powszechnej, a co za tym idzie - do szkół średnich.

\section{Bibliografia}

Araszkiewicz F.W., Ideały wychowawcze Drugiej Rzeczypospolitej, PWN, Warszawa 1978.

Araszkiewicz F.W., Szkoła średnia ogólnokształcąca w Polsce w latach 1918-1932, Zakład Narodowy im. Ossolińskich, Wydawnictwo PAN, Wrocław-Warszawa-Kraków-Gdańsk 1972.

Bardach J., Leśnodorski B., Pietrzak M., Historia ustroju i prawa polskiego, Lexis Nexis, Warszawa 2005.

Falski M., Fragmenty prac z zakresu oświaty 1900-1944, Zakład Narodowy im. Ossolińskich, Wydawnictwo PAN, Wrocław-Warszawa-Kraków-Gdańsk 1974.

Historia wychowania. Wiek XX, red. J. Miąso, PWN, Warszawa 1984.

Malec D., Malec J., Historia administracji nowożytnej, Wydawnictwo Uniwersytetu Jagiellońskiego, Kraków 1996.

Malec J., Malec D., Historia administracji i myśli administracyjnej, Wydawnictwo Uniwersytetu Jagiellońskiego, Kraków 2000.

Pęcherski M., Świątek M., Organizacja oświaty w Polsce w latach 1917-1969. Podstawowe akty prawne, Państwowe Wydawnictwo Naukowe, Warszawa 1972.

Suchodolski B., Edukacja narodu 1918-1968, Wiedza Powszechna, Warszawa 1970.

Trzebiatowski K., Szkolnictwo powszechne w Polsce w latach 1918-1932, Zakład Narodowy im. Ossolińskich, Wydawnictwo PAN, Wrocław-Warszawa-Kraków 1970.

Witkowski W., Historia administracji w Polsce 1764-1989, Wydawnictwo Naukowe PWN, Warszawa 2007.

Wroczyński R., Dzieje oświaty polskiej, t. 2: 1795-1945, Wydawnictwo Edukacyjne „Żak”, Warszawa 1996. 


\section{The administration of primary and secondary education in the Second Polish Republic}

\section{SUMMARY}

After Poland had regained its independence in 1918 the social interests in education and upbringing started to grow significantly. The school systems inhereted from the states during the times of partioned Poland needed to be unified in the whole country. The general opinion was that some basic legislative acts are required in the newly independent Republic of Poland to eliminate the differences between the regions and to provide a cohesive and uniform organisation of schools and education in the whole country.

The Minister of Religious Confessions and Public Education was in charge of the educational administration. In order to be able to supervise the educational administration the country was divided into ten school provinces supervised by province superintendents. The school provinces were divided into districts adminstrated by district superintendents. All the school systems inhereted from the time of the partioned Poland were unified by a legislative act of 1932. According to the reform implemented there were primary schools, secondary schools and higher schools. In terms of financing education the schools were public and private. The base was the seven-year primary education. However, to be able to classify the schools of that time according to the new organisational model it was necessary to implement a threestage structure of primary schools. The schools were divided into three stages teaching the following curriculums:

- primary curriculum (classes I - IV),

- higher curriculum (classes I - VI),

- complete curriculum (7 classes).

The reform of the secondary education introduced middle schools lasting four years and upper-secondary schools lasting two years. A prerequisite for pupils to be admitted to middle schools was a successful completion of the six-year primary school (and passing an examination). After completing a middle school and passing an entrance examination pupils were entitled to continue the education at secondary schools. The completion of the secondary education entitled them to take the Matura examination and then to apply for a place at a higher school. The Law of 1932 also enabled to organise vocational schools under similar terms.

\section{KEYWORDS}

history of administration, education in the Second Polish Republic 
